Volume 3 Issue 1, March 2018: pp. 1-10. Copyright @ LamLaj. Faculty of Law, Lambung Mangkurat University, Banjarmasin, South Kalimantan, Indonesia. ISSN: 2502-3136 | e-ISSN: 2502-3128.

Open Access at: http: / /lamlaj.ulm.ac.id/web/

\title{
THE LEGAL CONSEQUENCES REGARDING THE EXECUTION OF JOINT PROPERTY LAND OBTAINED DUE TRANSNATIONAL MARRIAGE IN INDONESIAN POSITIVE LAW
}

\begin{abstract}
Yati Nurhayati ${ }^{1}$ Ifrani $^{2}$
${ }^{1}$ Fakultas Hukum Uniska Banjarmasin, Jl. Adhyaksa N. 2 Kayutangi Banjarmasin Kalimata Selatan, email : nurhayati.law@gmail.com

${ }^{2}$ Fakultas Hukum Universitas Lambung Mangkurat. Jl.Brigjend H.Hasan Basri Komplek Banjarmasin 70123 Indonesia Fax:05114321658+E-mail :ifrani99@, gmail.com

Submitted : 27/02/2018 Reviewed 22/03/2018 Accepted:31/03/2018

Abstract:The arising issues of transnational marriage in Indonesia, Several problems they will face, among others will be concerning the children's nationality because they are subject to different laws, as well as problems with their properties that were obtained during marriage, that is frequently related to the land ownership of Indonesian Citizen. Especially the status of land property right owned by Indonesian citizens that was obtained due the transnational marriage according to Indonesian positive law and the execution of the joint property separation, in the form of land. The research method that is used is a normative juridical approach which analyzed based on the jurisprudence. Based on Indonesian positive law, the citizen who in the transnational marriage without prenuptial agreement, the rights status of his/her land in the form of property acquired jointly be equalized to his/ her partner is only the rights to use. The partition of land property acquired jointly when divorce occurs in a transnational marriage beyond the specified period time by the Indonesian Positive Law is not applicable based on article 21 paragraph (3) of UUPA.
\end{abstract}

Keywords: Mixed Marriage; Divorce; Property; Ownership; Land.

\section{INTRODUCTION}

After the 4th amendment of 1945 Constitution of Republic Indonesia (furthermore referred to as the 1945 Constitution), article 28B paragraph (1) stated that "every person shall have the right to form a family and to continue the offspring through legal marriage".
Marriage is the sacred covenant of forming a family between a man and a woman. Whereas marriage is an important event in the life of a fellow human being of a different kind to realize the unity of the household in the life of a husband and wife. In article 1 of Act No. 1 of 1974 says that marriage is the inner birth 
bond between a man and a woman as husband and wife with the aim of forming a happy and prosperous family based on the One God. The Indonesian nation as an independent and sovereign country creates a national legal system oriented and oriented towards Pancasila and the 1945 Constitution. With the presence of Law Number 1 Year 1974 on Marriage, the status of husband and wife is more concerned especially in the right and equal liability.

The problem of joint property in marriage, often is not thought by a lot of married couple or who's want to be. They just think that marriage is forever. It did not occur to them that someday the divorce might happen. They are just thinking about shared properties during the process or after the divorce. For this reason, discussions on this issue need to be raised in public discourse. Society needs an adequate knowledge of this issue which will open our knowledge, that the marital properties needs to be known from the beginning of the marriage of a couple of brides. The marital property is the property obtained by the couple jointly during the period marriage is still ongoing. Excluded from the category of joint property are property acquired or generated prior to their marriage (such as inheritance property) or personal property acquired after the marriage period commonly referred to as acquisition property.

The issue of joint property is often a hot issue in the society. Which ultimately seized the attention of the media, especially divorce news among a number of celebrities who came to a dispute about the distribution of joint property in marriage. Cases of divorce concerning the sharing of joint property among celebrities or politicians are often blow-up by the mass media. Couples who have divorced it is increasingly fussed with the problem of sharing the joint property that is famous for complicated and they are also the issue of child custody. Each side claimed each other that he was entitled to get a share of joint property greater than his partner.

Every married person wanted to form a happy and eternal family, but in reality not all marriages work well, problems in marriage can lead to a breakup in the future. In the event of separation or divorce it will create new problems, especially in the transnational marriage. Several problems they will face, among others will be concerning the children's nationality because they are subject to different laws, as well as problems with their properties that were obtained during marriage. The legal consequences of marriage are very important, not only in relation to their kinship, but also in the field of their property right. ${ }^{1}$ The recent problems from transnational marriages often occur in Indonesia is related to the ownership of land for Indonesian citizens in joint property as a result from transnational marriages.

Based on the data obtained at the Office of Population and Civil Registration Surabaya Municipality, in the year 2009 to October there were 34 couples marriage mix that held mixed marriage there. 29 of the 34 couples, who are Indonesian women married to foreign nationality men, while only 5 couples between foreign national women married to Indonesian men. This means that as many as $85 \%$ of married offenders are women of Indonesian citizens. The data is not much different from the results of Indonesian-Mixcouple Club (Indo-MC) research through online survey in 2000, from 574 respondents who captured $95.19 \%$ of mixed marriage perpetrators

1 J. Andy Hartanto. 2012. Hukum Harta Kekayaan Perkawinan. Yogyakarta : Laksbang Grafika, hlm 1. 
are Indonesian women who married foreign men. The same thing was encountered at the Jakarta Civil Registry Office in 2002 to 2004 of 878 mixed marriages, $94.4 \%$ were Indonesian women married to foreign men. ${ }^{2}$

Furthermore, based on the Open Data of Population and Civil Registration Service of DKI Jakarta Province, throughout 2013 in DKI Jakarta there were 373 marriages and 40 divorces of transnational marriages. While in 2014 there are 330 marriages and 49 divorces of transnational marriages recorded in DKI Jakarta. $^{3}$ The increasing number of divorces must have caused many civil problems, which is related to the ownership of lands for Indonesian citizen in marital property due to transnational marriages or marriages outside Indonesia.

Moreover, with the number of occupations, based on Regional Temporary Data of Foreign Residents, in DKI Jakarta 2015, mention the number of foreigners in Central Jakarta had 2944 male and 1182 female, in North Jakarta had 1868 male and 1050 female, West Jakarta were 1129 males and 664 females, in South Jakarta had 9634 males and 5663 females, and in East Jakarta had 199 males and

2 Leonora Bakarbessy dan Sri Handajani. 2012. "Kewarganegaraan Ganda Anak Dalam Perkawinan Campuran dan Implikasinya Dalam Hukum Perdata Internasional" . Perspektif Vol. XVII No.1 Tahun 2012 Edisi Januari. page.6.

3 Jakarta Open Data Dinas Pendudukan dan Pencatatan Sipil dan Jumlah Pelayanan Akta Perkawinan 2013, Jumlah Pelayanan Akta Perkawinan 2014 access at http://data.jakarta. go.id/dataset/jumlah-pelayanan-akta-perkawinandki-jakarta also look at Jumlah Pelayanan Akta Perceraian 2013 dan Jumlah Pelayanan Akta Perceraian 2014 access at http://data.jakarta. go.id/dataset/jumlah-pelayanan-akta-perceraiandki-jakarta on 22 July 2017, 21.20 o'clock wita.
121 females. ${ }^{4}$ Based on these data, it is very possible there will be an increase in transnational marriages in Indonesia. Therefore, it is very important for Indonesian citizens who are married to foreigners to obtain legal certainty about the separation of joint properties when divorce occurs in transnational marriages in Indonesia.

Based on the positive law prevailing in Indonesia, joint property in the marriage is regulated in Law no. 1 Year 1974 on Marriage, Book of Civil Code, and Compilation of Islamic Law. The arrangement of joint property in this marriage is legally recognized, including in terms of its management, use and distribution.

The problem of sharing common property is rarely solved completely and satisfactorily because many couples who do not make a marital agreement before marriage. In fact, this agreement is very important as a guide if one day married couples are forced to divorce because of their household problems that can not be solved by peaceful ways.

One of the objectives of the existence of law for human life is for the creation of a harmonious human life. On the one hand, human beings can defend rights, and likes to dislike, have to carry out obligations. On the other side, when the law is in the discourse of knowledge, the law not only serves as an instrument of justice but can also be used as a preventive shield for humans in general so that people can live in an orderly and peaceful manner. And when the law is directly applied through the institution of judicial power then

4 Jakarta Open Data Dinas Pendudukan dan Pencatatan Sipil, Data Orang Asing Sementara Perwilayah 2015, access at http://data.jakarta. go.id/dataset/data-jumlah-penduduk-asingsementara-di-dki-jakarta on 23 July 2017, 12.05 o'clock wita 
the law can be a source of conflict resolution that occurs. The benefits of the Marital Agreement can be seen on two main sides, namely the benefits of a marital agreement for the private life of each spouse and the benefits of a marital agreement if a husband-wife conflict arises in relation to the joint property of the judiciary.

\section{Problems Statement}

Based on the introduction as described above, the following problems that can be formulated regarding transnational marriage in Indonesia, which is:

1. How is the status of land property right owned by Indonesian citizens that was obtained due the transnational marriage according to Indonesian positive law?

2. What are legal consequences regarding the execution of joint property land obtained due the transnational marriage beyond time period determined by Indonesian positive law?

\section{Research Purposes}

Based on the description of the problems above, the writing of this article aims to:

1. Provide clarity regarding to the status of land property right own by Indonesian citizens that was obtained due the marriage with foreign nationals according to Indonesian positive law.

2. Provide legal certainty regarding a joint property separation in the form of land that was obtained due the transnational marriages that beyond time period determined by the Indonesia positive law.

\section{METHOD}

\section{Research Method}

The method used in this research is normative juridical approach. This method focuses on research on secondary data in the form of primary, secondary and tertiary legal material.

\section{Research Specifications}

The research specification used is analytical descriptive that is to describe the facts prevailing in society to obtain a comprehensive and systematic, factual and accurate description of the Legal Certainty and Legal Protection Aspect in solving the problem of property rights in the form of land when it occurs in mixed marriage. The description of this analysis is illustrated by the facts which is applicable in society to obtain a thorough and systematic description of the juridical aspect of Property in the form of land when it occurs in transnational marriage.

\section{Research Stages}

This research was conducted with 2 stages: Library Research and Field Research. Library research is done by collecting primary, secondary and tertiary legal materials, as Mukti Fajar ND ${ }^{5}$ dividing it into the primary legal material of the

1. 1945 Constitution of the Republic Indonesia;

2. Book of Civil Code;

3. Law No. 5 Year 1960 on Basic Regulation of Agrarian Principles; National Document of Republic Indonesia No.104 Year 1960; Additional Document No. 2043

4. Law No. 1 Year 1974 on Marriage; National Document of Republic Indonesia No.1 Year 1974; Additional Document No. 3019

5. Law No. 12 Year 2006 on Citizenship of the Republic of Indonesia; National Document of Republic Indonesia No.63 Year 2006; Additional Document No.

5 Mukti Fajar ND.2010. Dualisme Penelitian Hukum Normatif dan Empiris. Yogyakarta: Pustaka Pelajar, hlm.157. 
4634

6. Government Regulation No. 24 Year 1997 on Land Registration; National Document of Republic Indonesia No.59 Year 1997; Additional Document No. 3696

7. Government Regulation No. 37 Year 1998 on The Officials Regulation of the Land Authority; National Document of Republic Indonesia No.52 Year 1998; Additional Document No. 3746

8. Presidential Regulation No. 20 Year 2015 on The National Land Agency; National Document of Republic Indonesia No.21 Year 2015

Another legal substance is a secondary legal material that is legal material that can provide explanations of primary legal materials, which can be draft legislation, research results, textbooks, scientific journals, and internet news. According to Peter Mahmud Marzuki, the subject of secondary law research is material in the form of all legal publications that are not official documents, including textbooks, legal dictionaries, legal journals, and comments on court verdicts. ${ }^{6}$ Secondary legal materials provide explanations of primary legal materials such as: books, research results and scientific work of law circles relating to the legal certainty aspects in land ownership rights.

The tertiary legal material is the legal material used by researchers in the form of Indonesian Dictionary which also can support the material of Primary and secondary legal materials.

The second stage is field of research. This field of research is used to support the library data. It was conducted to the competent par-

6 Peter Mahmud Marzuki. 2006. Penelitian Hukum, Jakarta: Kencana, page. 141 ties that include Government Officials, Lawyers, and the community related to the topics.

Analysis of legal materials uses qualitative that is by performing processes, analysis and construct the data as a whole and systematic by explaining the relationship between various types of data with the problems in the perusal. According to Sugiyono ${ }^{7}$ qualitative research is a research method based on postpositivism philosophy, used to examine the natural object condition where the researcher is a key instrument, the determination of the informant is done purposely, the collection technique with triangulation, the data analysis is inductive/qualitative. The research uses the normative legal research by interpreting and constructing the law the draws the conclusion using deductive way to answer the problems and the aims of research specified.

\section{Data Collections Technique}

To obtain the relevant data to the problems studied then carried out with two stages of research are:

1. Library Study.

Library study is a method of collecting data by finding and studying concepts, theories, books, and opinions or findings that are closely related to the subject matter.

\section{Interview}

Interviews are means of collecting data by holding questions orally and directly with the parties directly related to the problems studied. The parties directly and competently involved in the study include the Parties that conduct a transnational marriage, the South Jakarta District Court (Judge, the Registrar), and the South Jakarta Land Office.

$7 \quad$ Sugiyono. 2009. Metode Penelitian Kuantitatif Kualitatif dan R\&D. Bandung: Alfabeta, page.15 
Against these legal materials the analysis is done in a qualitative way, meaning without using numbers, statistical formula, and mathematics.

\section{ANALYSIS AND DISCUSSION}

Land Ownership Status in Transnational Marriage Based on Indonesian Positive Law

Article 28B Paragraph (1) of the 1945 Constitution states that "every person shall have the right to form a family and continue his offspring through legal marriage." Marriage is a very important institution in society. The existence of this institution is to legalize the legal relationship between a man and a woman. ${ }^{8}$ Marriage as part of civil law is the law regulations that adjusting the legal acts and legal consequences between two parties, namely a man with a woman with the intention of living together for a long time according to the rules set out in law. ${ }^{9}$

Based on Article 57 of Law No.1 Year 1974 on Marriage, the meaning of Mixed Marriage is a marriage between two persons in Indonesia and subject to different laws because of differences in citizenship and one of the party is Indonesian citizens. If the marriage takes place between two Indonesians of different religions, not included in mixed marriages, but the marriage of different religions. ${ }^{10}$

Article 60 of Law No. 1 Year 1974, state that mixed marriages can not take place before it is proved that the terms of marriage prescribed by law that applicable to their re-

8 Titik Triwulan Tutik. 2006. Pengantar Hukum Perdata di Indonesia. Jakarta : Prestasi Pustaka Publisher, page.106.

$9 \quad$ Ibid, page. 103.

10 Irma Devita Purnamasari.2014. Kiat-kiat Cerdas, Mudah dan Bijak Memahami Masalah Hukum Waris. Bandung : Mizan Pustaka, page. 156. spective parties have been complied with, as evidenced by a certificate that the terms have been met by the authorities to register the marriage under the law.

If the official refuses to provide a certificate, then at an interest request, the Court provides a decision (with no lawyer and no appeal), whether the refusal to grant the certificate is justified or not. If the Court decides that the refusal is unreasonable, then the decision becomes a substitute for the description. An explanatory statement or a substitute decision shall have no further power if the marriage does not take place within a period of 6 (six) months after the information is given.

However, if the marriage is outside Indonesia as provided for in Article 56 of the Marriage Law:

(1) Marriage held outside Indonesia between two Indonesian citizens or an Indonesian citizen with a foreign citizen is lawful if done under applicable law in the country where the marriage is held and for Indonesian citizens do not violate the provisions of this Act.

(2) Within 1 (one) year after the husband and wife are back in the territory of Indonesia, their marriage certificate must be registered at the Marriage Registering Office where they live.

Based on that article, in terms of marriage outside Indonesia, the provisions that must be met include subject to the law in which country the marriage takes place. If persons did the marriage in Singapore, the marriage must comply with Singaporean law, and then be registered with the local Civil Registry. For Indonesian Citizen, marriage must do not violate the provisions of the Indonesian Marriage Law. That is mean, he or she must still be subject to the provisions of the Indonesian 
Marriage Law. If the marriage is to be conducted outside Indonesia, they must register and report to the Department of Population and Civil Registry in Indonesia within 1 (one) year.

The provisions of marriage have been regulated very detail in Law No. 1 Year 1974 on Marriage. This law establish about marriage, the result of a marriage, and mixed marriage. Furthermore under the provisions of Article 58 of the Marriage Law it is stated that mixed marriages may result in the acquisition or loss of citizenship. A marriage can take place, both inside and outside the country, while the subjects may be Indonesian citizens or foreign nationals. The marriage must in accordance with the usual ways in which the marriage takes place. Where legislation is violated, marriages abroad may be declared invalid by the judge with reasons and the parties' lawsuit, as well as marriages held in the country (Indonesia). ${ }^{11}$ UUPA states that only Indonesian citizens can have the right of land ownership status. For foreigners, it will be difficult to own land or buildings with ownership status. ${ }^{12}$

According to article 21 paragraph (3) of the UUPA, with the mixing of property due to marriage, for Indonesian citizens in a mixed marriage, the main requirement to obtain land ownership rights is having single Indonesian nationality (not a bipatride) and holds a mar-

11 R. Soetojo Prawirohamidjojo dan Marthalena Pohan.1991. Hukum Orang dan Keluarga. Surabaya : Airlangga University Press, page. 3132.

12 Rangga Raditya. Kedudukan Harta Suami Dan Istri Yang Berupa Tanah Di Dalam Perkawinan Campuran Sesudahnya Berlaku Undang-undang No. 1 Tahun 1974., access from https://lib.atmajaya. ac.id/default.aspx?tabID $=61 \&$ src $=k \& i d=178056$, on 11 October 2015, at 10.49 o'clock wib. riage agreement. Article 24 Paragraph (4) of the UUPA state that as long as a person has Indonesian nationality in addition has foreign nationality as well, he/she can not own land with ownership right. This means that during that time the status of land ownership will be as well as for foreigner nationality. So the article stressed that person who can have the land with ownership right is only a citizen of Indonesia with only single nationality.

UUPA adheres to the principle of nationality, the principle that stated only Indonesian that can have full legal contact with earth, air, space, and wealth contained in it. Principle of nationality adopted by UUPA can be seen in article 9 of UUPA which is stated:

(1) Only Indonesian Citizens may have complete contact with earth, water and space within the limits of the provisions of Articles 1 and 2.

(2) Every Indonesian citizen, both men and women have equal opportunity to obtain a right to land and to obtain benefits and results, both for themselves and their families.

The status of land ownership rights for foreign nationals is regulated in Article 21 paragraph (3) of Law No. 5 Year 1960 on Basic Regulation of Agrarian Principles (UUPA). Foreign nationals who acquire property rights inheritance shall be obliged to relinquish their acquired rights within a period of 1 (one) year, and the property rights acquired by foreign nationals for the mixing of property (in the absence of a marriage agreement) resulting from a mixed marriage. It is also valid for an Indonesian citizen who has engaged in a mixed marriage with the ownership right, should detach the right in a period of 1 (one) year, because he/she has lost his/ her nationality. The article applies to mixed 
marriages that did not made a marriage agreement. Detaching the rights can be done by selling or granting the rights of the land.

The status of land ownership rights for Indonesian citizens who are married to foreigners according to the Indonesian Positive Law is for Indonesians who are marriages with unconditional of separation of property, the status of the land which is a joint property to be equated with his or her spouses, that is only limited to the right to use not ownership right. This is because there is a mixture of property with his/her foreign partner. Then after marriage, all of personal properties will become marital joint properties, based on Article 35 of the Marriage Law, so the husband who has foreign nationality will participate of owning the properties which lead to joint property. In accordance with the UUPA, foreigners with possession of land only has the right of use.

The Legal Consequences Regarding The Execution of Joint Property Land Obtained Due The Transnational Marriage Beyond Specified Period by Indonesian Positive Law

The rights and obligations of transnational married couples is not regulated either by Law Number 1 Year 1974 or in the Compilation of Islamic Law (President Instruction Number 1 Year 1991), in which case all rights and obligations of husband and wife in the regular marriages and transnational marriages are the same. For Law Number 1 Year 1974 is set forth in Chapter VI, Articles 30 through 34, while according to the provisions of the Compilation of Islamic Law set out in Chapter XII, Articles 77 to $84 .^{13}$

13 Laurensius Mamahit. 2013. "Hak dan Kewajiban Suami Isteri Akibat Perkawinan Campuran Ditinjau Dari Hukum Positif Indonesia”. Lex Privatum. Vol.I/No.1/Jan-Mrt/2013, page.24.
Indonesians who are married to foreigners, after the marriage, are not allowed to have rights to land in the form of Ownership Rights, Cultivation Rights or Building Rights. This is in accordance with Article 35 of the Marriage Law which states that property acquired during marriage becomes a common property. So there is a mixture of properties gained after marriage, and the spouse (who is a foreign national) will also be the owner of the joint properties. While referring to the provisions of Law No. 5 Year 1960 on Basic Regulations of Agrarian Principles, foreigners may not own the Ownership Rights, Cultivation Rights or Building Rights.

Indonesian citizen who marries a foreign national, if she or he wish to retain the right to land after marriage, they have to make a marriage agreement or prenuptial agreement concerning the separation of their property and the property of their spouse.

So this is very important to create a marital agreement authorized by the Employee of the Marriage Register shall be binding and applicable as a law to the prospective husband and wife and a third party, as far as the parties are involved.

If a marriage agreement that a husband and wife have made is not enforced or a breach of the contract is made, it automatically grants the wife the right to request the cancellation of the marriage or as the reason for the divorce suit.

The property of husband and wife, in Act No. 1 Year 1974 is under the control of each other if not otherwise determined through the agreement. The deviation from the principle is made possible by the law insofar as it does not violate the boundaries of law, religion and morals. If the basis of marriage according to the limits of Article 1 of Law No. 1 Year 1974 
really animates it's inner birth bond, then the properties should be a unanimously mixed. Unless if it's possible to shared profit-loss and profit-income. In this case the purpose of the marriage agreement is the release of the personal rights of each husband and wife in absolute terms that become marital property or limit their rights, such as not including deposits, savings, jewelry or high heirlooms, and others. While the benefits are strengthening the bond of inner birth of Article 1 while also foster mutual trust in implementing the rights and obligations of husband and wife. ${ }^{14}$

The Marital Agreement is not only about rights but also related to obligations. In relation to property can be tangible property in the sense that property is actually in the hands of the husband and wife and intangible property in the sense of property owned by a husband and wife in the hands of third parties in the form of receivables or property of third parties who in the hands of husband and wife in the form of debt. ${ }^{15}$

Other several benefits of creating a marital agreement for each individual's life, the parties, those who make the covenant both husband and wife have the freedom of action, freedom of action to take legal action and make use of it. Besides having the freedom of action also the enforcement sense of justice, the improvement of work quality and an increase in the level of the economy of the State. The benefits of a marriage agreement in case of dispute resolution can save time and money of litigation.

The marriage agreement may be made on

14 Felicitas Marcelina Waha. 2013. "Penyelesaian Atas Sengketa Harta Perkawinan Setelah Bercerai". Lex Et Societatis Vol.I/No.1/JanMrt/2013, page.62.

15 Ibid, page. 63 before or during the marriage bond. This has been regulated in Article 29 of the Marriage Law juncto Constitutional Court Decision Number 69 / PUU-XIII / 2015:

1. At the time, prior to proceeding or during the marriage bond, the two parties with mutual consent may file a written agreement authorized by the marriage or notarial employee, which after, the content also applies to the third parties as long as the third party is involved.

2. The Agreement can not be ratified if it violates legal, religious and moral boundaries.

3. The Agreement shall be in effect upon the date of marriage, unless otherwise specified in the Marriage Agreement.

4. During marriage, the agreements may be related to marital property or other agreements are irreversible or revoked, unless on both sides has agree to amend or withdraw, and such amendment or revocation shall not harm the third party.

Based on the Letter of the Director General of Population and Civil Registration of the Ministry of Home Affairs No. 472.2 / 5876 / DUKCAPIL dated May 19, 2017, the marriage agreement may be made before, at the time, and during the marriage takes place by notarial deed and reported to the Implementing Agency or Technical Implementation Unit ("UPT") Executing Agency. In relation to the reporting of the marriage agreement, the Civil Registry Official of the Implementing Agency or "UPT" of the Implementing Agency shall make marginal notes on the register of deeds and citations of the marriage certificate.

The separation of joint property in the form of land when the divorced of mixed marriage at the time determined by the Indonesian Positive Law cannot be apply accord- 
ing to Article 21 paragraph (3) of the UUPA. The husbands and the wives which are not relinquish their property rights as their joint property for more than 1 (one) year, the property should become the State Property.

However, there is one way to execute lands without marital agreement like a case when a couple have a land with the name of another person who is an Indonesian Citizen listed in the certificate they can still share the land as a joint property. For example, SB is a Foreign Citizen and AR is an Indonesian Citizen. They are transnational marriage couple who were divorced, but SB and AR can share their joint property. This is because during the time of marriage they cultivate and used the land with the name listed on the SHM (certificate of ownership) was the previous owner named HW who is an Indonesian Citizen. Therefore, SB and AR cannot be imposed with Article 21 paragraph (3) of UUPA and $\mathrm{SB}$ still retain his share of the land even without previous agreement.

\section{CONCLUSION}

1. The provisions of marriage have been regulated very detail in Law No. 1 Year 1974 on Marriage. This law establish about marriage, the result of a marriage, and mixed marriage. Furthermore under the provisions of Article 58 of the Marriage Law it is stated that mixed marriages may result in the acquisition or loss of citizenship. A marriage can take place, both inside and outside the country, while the subjects may be Indonesian citizens or foreign nationals. The marriage must in accordance with the usual ways in which the marriage takes place. Where legislation is violated, marriages abroad may be declared invalid by the judge with reasons and the parties' lawsuit, as well as marriages held in the country (Indonesia). Indonesian citizens in transnational marriage without a prenuptial agreement on separation of property, the status of rights to land in the form of joint property will be equalized with his foreign partner, which is limited only to the right of use. This is because there is a mixing of property with her foreign partner, then after the marriage of property acquired during marriage is a joint property referring to Article 35 of the Marriage Law. So this is very important to create a marital agreement authorized by the Employee of the Marriage Register shall be binding and applicable as a law to the prospective husband and wife and a third party, as far as the parties are involved.

2. The execution of land property without previous marital agreement when divorced occurs in a mixed marriage beyond the time period determined by the Indonesian Positive Law cannot be done due to Article 21 paragraph (3) of the UUPA. The legal consequence for husband and wive who are not give up their ownership of the joint property for more than 1 (one) year is that the property should be falls to the State. However, there are other case when the couple has a land listed with name of another person who has status as an Indonesian Citizen listed in the certificate they can remain share land as a joint property. For example, SB is a Foreign Citizen and AR is an Indonesian Citizen. They are a transnational marriage couple who was divorced, but SB and AR can shared their joint property. This is because during the time of marriage they cultivate and use the land with the name listed on the SHM (cer- 
tificate of ownership) was the previous owner named HW who is an Indonesian Citizen. Therefore, SB and AR cannot be imposed with Article 21 paragraph (3) of UUPA and SB still retain his share of the land even without marital agreement.

\section{Suggestion}

1. Indonesian Citizens who are engage in the transnational marriage should create a marital agreement regarding the management of joint property acquired during the marriage, because in reality not all marriages can go well, The legal consequences caused by marriage is very important, not only in relation to kinship, but also in the field of property right.

2. Indonesian Citizens who want to keep their land without any marital agreement could used their land with the previous owner name listed in certificate. In order to maintain their rights, so it could be execute in the future.

\section{BIBLIOGRAPHY}

Ermoshuizen, Marjanne. 2002. Kamus Hukum Belanda-Indonesia. Jakarta: Djambatan.

Felicitas Marcelina Waha. 2013. "Penyelesaian Atas Sengketa Harta Perkawinan Setelah Bercerai”. Lex Et Societatis Vol.I/ No.1/Jan-Mrt/.

Hartanto, J. Andy. 2012. Hukum Harta Kekayaan Perkawinan. Yogyakarta: Laksbang Grafika.

Jakarta Open Data Dinas Pendudukan dan Pencatatan Sipil, Jumlah Pelayanan Akta Perkawinan 2013 dan Jumlah Pelayanan Akta Perkawinan 2014, diakses melalui http://data.jakarta.go.id/dataset/jumlahpelayanan-akta-perkawinan-dki-jakarta pada tanggal 22 Juli 2017, Pukul 21.20 wita

Jakarta Open Data Dinas Pendudukan dan Pencatatan Sipil, Data Orang Asing Sementara Perwilayah 2015, diakses melalui http://data.jakarta.go.id/dataset/ data-jumlah-penduduk-asing-sementaradi-dki-jakarta pada tanggal 23 Juli 2017, Pukul 12.05 wita.

Laurensius Mamahit. 2013. "Hak dan Kewajiban Suami Isteri Akibat Perkawinan Campuran Ditinjau Dari Hukum Positif Indonesia" Lex Privatum. Vol.I/No.1/ Jan-Mrt/2013.

Leonora Bakarbessy \& Sri Handajani. 2012. "Kewarganegaraan Ganda Anak Dalam Perkawinan Campuran dan Implikasinya Dalam Hukum Perdata Internasional" Perspektif Vol.XVII No.1 Tahun 2012 Edisi Januari

Marzuki, Peter Mahmud. 2006. Penelitian Hukum. Jakarta : Kencana.

ND, Mukti Fajar. 2010. Dualisme Penelitian Hukum Normatif dan Empiris. Yogyakarta: Pustaka Pelajar.

Prawirohamidjojo, R. Soetojo dan Marthalena Pohan. 1991. Hukum Orang dan Keluarga. Surabaya : Airlangga University Press.

Purnamasari, Irma Devita, 2014. Kiat-kiat Cerdas, Mudah dan Bijak Memahami Masalah Hukum Waris. Bandung: Mizan Pustaka.

Rangga Raditya, Kedudukan Harta Suami Dan IstriYangBerupaTanahDiDalamPerkawinan Campuran Sesudahnya Berlaku Undang-undang No. 1 Tahun 1974, diakses dari https://lib.atmajaya.ac.id/default. aspx? tabID $=61 \& s r c=k \& i d=178056$, pada tanggal 11 oktober 2015, Pukul 10.49 wib

Sugiyono. 2009. Metode Penelitian Kuanti- 
tatif kualitatif dan $R \& D$. Bandung: Alfabeta.

Tutik, Titik Triwulan. 2006. Pengantar Hukum Perdata di Indonesia.Jakarta: Prestasi Pustaka Publisher

\section{Law and Regulations}

Law No. 1 Year 1974 on Marriage; National Document of Republic Indonesia No.1 Year 1974; Additional Document No. 3019

Law No. 5 Year 1960 on Basic Regulation of Agrarian Principles; National Document of Republic Indonesia No.104 Year 1960; Additional Document No. 2043

Law No. 12 Year 2006 on Citizenship of the Republic of Indonesia; National Document of Republic Indonesia No.63 Year 2006; Additional Document No. 4634

Presidential Regulation No. 20 Year 2015 on The National Land Agency; National Document of Republic Indonesia No.21 Year 2015

Government Regulation No. 24 Year 1997 on Land Registration; National Document of Republic Indonesia No.59 Year 1997; Additional Document No. 3696

Government Regulation No. 37 Year 1998 on The Officials Regulation of the Land Authority; National Document of Republic Indonesia No.52 Year 1998; Additional Document No. 3746 